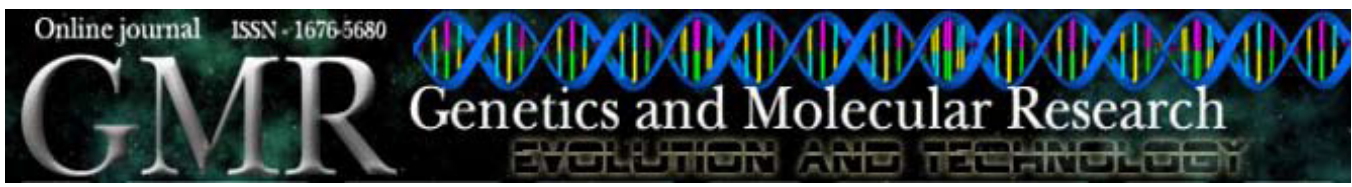

\title{
Isolation and characterization of NBS-LRR- resistance gene candidates in turmeric (Curcuma longa cv. surama)
}

\author{
R.K. Joshi, S. Mohanty, E. Subudhi and S. Nayak \\ Centre of Biotechnology, Siksha O Anusandhan University, \\ Bhubaneswar, India \\ Corresponding author: R.K. Joshi \\ E-mail: rajkumar.joshi@yahoo.com
}

Genet. Mol. Res. 9 (3): 1796-1806 (2010)

Received June 10, 2010

Accepted July 18, 2010

Published September 8, 2010

DOI 10.4238/vol9-3gmr910

\begin{abstract}
Turmeric (Curcuma longa), an important asexually reproducing spice crop of the family Zingiberaceae is highly susceptible to bacterial and fungal pathogens. The identification of resistance gene analogs holds great promise for development of resistant turmeric cultivars. Degenerate primers designed based on known resistance genes (R-genes) were used in combinations to elucidate resistance gene analogs from Curcuma longa cultivar surama. The three primers resulted in amplicons with expected sizes of 450-600 bp. The nucleotide sequence of these amplicons was obtained through sequencing; their predicted amino acid sequences compared to each other and to the amino acid sequences of known R-genes revealed significant sequence similarity. The finding of conserved domains, viz., kinase-1a, kinase-2 and hydrophobic motif, provided evidence that the sequences belong to the NBS-LRR class gene family. The presence of tryptophan as the last residue of kinase-2 motif further qualified them to be in the non-TIRNBS-LRR subfamily of resistance genes. A cluster analysis based on the neighbor-joining method was carried out using Curcuma NBS analogs together with several resistance gene analogs and known R-genes,
\end{abstract}


which classified them into two distinct subclasses, corresponding to clades N3 and N4 of non-TIR-NBS sequences described in plants. The NBS analogs that we isolated can be used as guidelines to eventually isolate numerous R-genes in turmeric.

Key words: Resistance gene analogs; Multiple sequence alignment; NBS-LRR; R-genes

\section{INTRODUCTION}

Turmeric, also known as the "golden spice", is one of the most important herbs in tropical and sub-tropical countries. Turmeric rhizome is valued worldwide and has been in use since ancient times as a spice, food preservative and dye, and in traditional medicine (Ravindran et al., 2007). Its medicinal uses are indeed diverse, ranging from cosmetic face cream to a preventive medicine against Alzheimer's disease. Turmeric is also qualified as the queen of natural Cox-2 inhibitors (Duke, 2003). India is the world's largest producer and exporter of turmeric, followed by China, Indonesia, Bangladesh, and Thailand (Selvan et al., 2002). The International Trade Centre, Geneva, has estimated an annual growth rate of $10 \%$ in the world demand for turmeric. Conventional crop improvement methods are not suitable because turmeric is not only completely sterile but also propagates exclusively by vegetative means. It is a well-known fact that the genotypic diversity of exclusively asexually reproducing plants will be lost in the long course of evolution. Moreover, most of the turmeric cultivars available today are equally susceptible to major diseases such as rhizome rot caused by Pythium spp, leaf blotch caused by Taphrina maculans and leaf spot caused by Colletotrichum capsici. Hence, the cloning of resistance genes and subsequent transformation is the only solution to obtain disease-resistant turmeric cultivars.

Plant resistance genes are an important component of the genetic resistance mechanism in plants (Flor, 1956). A large number of plant resistance genes have been isolated and cloned based on positional or map-based cloning and transposon tagging, such as tobacco $N$ (Whitham et al., 1994), Linium L6 (Lawrence et al., 1995), Arabidopsis RPS2 (Bent et al., 1994), rice Xa21 (Song et al., 1995), etc. However, this process of cloning is not possible in asexually reproducing turmeric, as it is very cumbersome, complicated and difficult. In recent times, structural analyses of cloned resistance genes have led to the identification of conserved regions in the structural domains and sequences involved in protein-protein interaction and signal transduction (Baker et al., 1997; Gassmann et al., 1999). Based on these conserved motifs, R-genes have been grouped into five classes (Hammond-Kosack and Jones, 1997).

Class I is represented by the maize $H M 1$ gene, which encodes a reductase that detoxifies $\mathrm{HC}$ toxin of the fungus Cochliobolous carbonum. Class II is represented by the majority of functionally known R-genes ( $R P S 2, R P M 1, N, L 6$, etc.), which encode cytoplasmic receptor-like proteins that contain a leucine-rich repeat (LRR) domain and nucleotide-binding site (NBS). Class III includes the Pto gene from tomato, which does not have an NBS-LRR domain but encodes a protein with a serine-threonine protein kinase domain. Class IV includes the Xa21 gene of rice, which encodes an extra-cytoplasmic LRR domain and an intracellular serine/threonine kinase domain, while class $\mathrm{V}$ represents the $C f$ genes of tomato 
that encode transmembrane receptors with an extracellular LRR domain and an intracellular serine-threonine kinase. It has been observed that most of the known R-genes possess conserved amino acid motifs along the NBS sequence. This includes the P-loop and the kinase-2 domains, which are ATP- and GTP-binding sites (Traut, 1994; Meyers et al., 1999), the kinase-3a domain and the putative membrane spanning hydrophobic GLPL domain (Baldi et al., 2004). These conserved domains in genes offer opportunities for designing simple polymerase chain reaction (PCR)-based strategies with degenerate primers for the amplification and isolation of similar sequences in other plant species (Kanazin et al., 1996). The structural specificity has made it possible to isolate potential resistance gene analogs (RGAs) by homology-based techniques in different plant species such as soybean (Kanazin et al., 1996; He et al., 2003), maize (Collins et al., 1998), lettuce (Shen et al., 1998), rice (Mago et al., 1999), common bean (Rivkin et al., 1999), citrus (Deng et al., 2000), wheat (Lacock et al., 2003), sorghum (Totad et al., 2005), and ginger (Nair and Thomas, 2007). The RGA fragments were also used as molecular markers for tagging the disease resistance loci in Arabidopsis (Aarts et al., 1998), rice (Ilag et al., 2000), tomato (Zhang et al., 2002), etc. Some RGAs have been demonstrated to be linked with known R-genes, and the wheat $\operatorname{Lr} 10$ gene has been successfully cloned by this method (Feuillet et al., 1997).

In the present study, we used three pairs of degenerate oligonucleotide primers based on the NBS domain of resistance genes, and obtained new resistance gene analogs from the Curcuma longa resistant cv. surama by PCR analysis and studied the sequencing and diversity of the NBS-LRR class of RGAs obtained from Curcuma by comparison with known resistance gene sequences.

\section{MATERIAL AND METHODS}

Total genomic DNA was isolated from the combined leaves of 10 turmeric plants of germplasm C. longa cv. surama using the protocol described by Doyle and Doyle (1990) with required modifications. The cultivar surama carries high levels of resistance to rhizome rot and leaf blotch. The quality and quantity of the DNA were determined with a Thermo Scientific UV-Vis spectrophotometer. Three R-gene-specific degenerate oligonucleotide primers that had previously been used in other taxa (Kanazin et al., 1996; Ohmori et al., 1998; Mago et al., 1999; Nair and Thomas, 2007) were selected. The genes and their conserved motifs, which formed the basis for primer design, are given in Table 1. The selected set of primers were designed according to the conserved P-loop (GGVGKTT) and hydrophobic domain (GLPLAL) from the N, L6 and RPS2 genes of the NBS-LRR class specific against pathogens. The primers were designed in such a way that around 500-bp PCR products were obtained upon amplification.

\begin{tabular}{|c|c|c|c|c|}
\hline Primer code & Sequences (5'-3') & Conserved motif & R-gene & References \\
\hline Cl-1 & $\begin{array}{l}\text { GGIGGIRTIGGIAARACIAC } \\
\text { WTIARIGYIARIGGIARICC }\end{array}$ & $\begin{array}{l}\text { P-loop } \\
\text { GLPL }\end{array}$ & $\begin{array}{l}N, R P S 2, L 6 \\
N, R P S 2\end{array}$ & Rivkin et al., 1999; Ohmori et al., 1998 \\
\hline $\mathrm{Cl}-2$ & $\begin{array}{l}\text { GGIGGIGTIGGIAAIACIAC } \\
\text { ARIGCTARIGGIARICC }\end{array}$ & $\begin{array}{l}\text { P-loop } \\
\text { GLPL }\end{array}$ & $\begin{array}{l}N, R P S 2, L 6 \\
N, R P S 2\end{array}$ & Kanazin et al., 1996; Nair and Thomas, 2007 \\
\hline Cl-3 & $\begin{array}{l}\text { GGTGGGGTTGGGAAGACAACG } \\
\text { CCACGCTAGTGGCAATCC }\end{array}$ & $\begin{array}{l}\text { P-loop } \\
\text { GLPL }\end{array}$ & $\begin{array}{l}N, R P S 2, L 6 \\
N, R P S 2, L 6\end{array}$ & Mago et al., 1999 \\
\hline
\end{tabular}




\section{Amplification and sequencing of NBS-like sequences using degenerate primers}

PCR was carried in a $50-\mu \mathrm{L}$ reaction mixture with $25 \mathrm{ng}$ template DNA, $200 \mathrm{nM}$ of each forward and reverse primer, $200 \mu \mathrm{M}$ of each dATP, dCTP, dGTP, and dTTP, 10X PCR buffer $\left(16 \mathrm{mM}(\mathrm{NH})_{2} \mathrm{SO}_{4}, 67 \mathrm{mM}\right.$ Tris- $\left.\mathrm{HCl}, 15 \mathrm{mM} \mathrm{MgCl}_{2}\right)$ and $1 \mathrm{U}$ Taq DNA polymerase (Bangalore Genie, India). PCR was performed in a Veriti thermal cycler (Applied Biosystems) using the following cyclic conditions: initial denaturation at $94^{\circ} \mathrm{C}$ for $5 \mathrm{~min}$ followed by 42 cycles each consisting of DNA denaturation at $94^{\circ} \mathrm{C}$ for $1 \mathrm{~min}$, primer annealing at $50 / 60^{\circ} \mathrm{C}$ for $1 \mathrm{~min}$ and primer extension at $72^{\circ} \mathrm{C}$ for $1 \mathrm{~min}$, and a final extension for 7 min. PCR products were subjected to electrophoresis on a $1.5 \%$ agarose gel in $0.5 \mathrm{X}$ TAE buffer, at $60 \mathrm{~V}$ for $1 \mathrm{~h}$. The photographs of gels were taken using a gel documentation system (Biorad) for recording and analysis. The PCR-amplified products were gel eluted and purified using GFX Gel Band Purification kit (Amersham Biosciences) and subsequently sequenced using BigDye Terminator Cycle Sequencing kit (Perkin Elmer) on an ABI Prism 310 Genetic Analyzer (Applied Biosystems).

\section{Sequence analysis}

A total of 5 of 17 sequenced fragments gave DNA sequence information with a high level of accuracy and were submitted to sequence analysis. The nucleotide sequences were translated and the corresponding amino acid sequences were aligned with NBS domain encoded by cloned R-genes using the CLUSTALX software (Thompson et al., 1997) in order to look for motifs characteristic of resistance proteins. Homology search was performed using the default settings of BLASTp with non-redundant GenBank database (http://www.ncbi.nlm.nih.gov) to identify resistance gene analogues as well as other homologous sequences in the database (Table 1). Amino acid sequences from resistance genes from other plant species were added to the set of NBS sequences, and cluster analysis was carried out using the CLUSTALX package based on the neighbor-joining method (Saitou and Nei, 1987) and drawn by TREEVIEW (Page, 1996).

\section{RESULTS}

\section{PCR amplification of targeted RGA fragment}

Altogether, 8 bands ranging from 0.2 to $1.2 \mathrm{~kb}$ in size were scored from three primers. All three primer pairs produced a major band of the expected size according to the source species from which the primers were designed and other species reported in the literature (Figure 1). Primer $\mathrm{Cl}-1-\mathrm{F} / \mathrm{Cl}-1-\mathrm{R}$ amplified two bands of 350 and $500 \mathrm{bp}$ with the latter being the target fragment. Primer Cl-2-F/Cl-2-R also amplified a target fragment of $500 \mathrm{bp}$. In addition, another thin fragment of 200 bp was also amplified, which was not as prominent. Similarly, primer $\mathrm{Cl}-3-\mathrm{F} / \mathrm{Cl}-3-\mathrm{R}$ amplified three additional bands besides the 600-bp target fragment. Three target-specific amplicons, one from each primer, were subjected to sequencing and 17 sequences were obtained. Five of 17 sequenced fragments gave DNA sequence information with a high level of accuracy to NBS sequences and were named $C R G A 1, C R G A 2, C R G A 3$, $C R G A 4$, and CRGA5. These fragments are deposited in the GenBank database (http://www. ncbi.nlm.nih.gov) and their accession numbers are HM117001 to HM117005. 


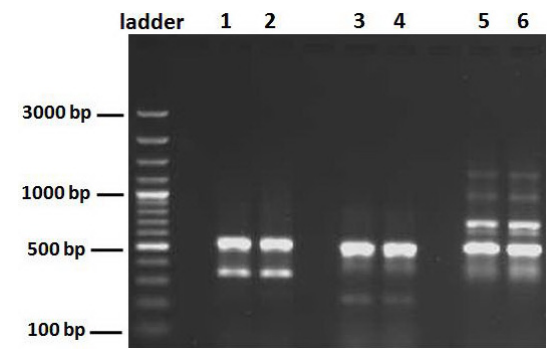

Figure 1. Polymerase chain reaction (PCR) product amplified from three pairs of degenerate primers from template DNA of Curcuma longa cv. surama. The primer pairs used for PCR and the expected size of the amplified bands are: Lanes 1 and $2=\mathrm{Cl}-\mathrm{F} 1 / \mathrm{Cl}-\mathrm{R} 1,550$ and $350 \mathrm{bp}$; Lanes 3 and $4=\mathrm{Cl}-\mathrm{F} 2 / \mathrm{Cl}-\mathrm{R} 2,500 \mathrm{bp}$; Lanes 5 and $6=\mathrm{Cl}-\mathrm{F} 3 /$ Cl-R3, 550 bp.

\section{BLASTp for identical protein sequences}

The nucleotide sequences were translated into polypeptides using the ExPaSy translate tool and identity search was made with the BLASTp algorithm. All four NBS analogs showed desirable similarity with RGAs deposited in the gene bank (Table 2). The NBS ana$\log$ CRGA4 showed $85 \%$ identity (E value $2 \mathrm{e}^{-11}$ ) with CC-NBS-LRR protein of Solanum tuberosum (GI: ABR29793) followed by $65 \%$ identity (E value $7 \mathrm{e}^{-13}$ ) with resistance gene analog (S. phureja x S. stenotomum) (GI: AAL30114) and 61\% identity (E value $3 \mathrm{e}^{-11}$ ) with putative disease resistance protein nbs-1rr of S. dimissum. CRGA3 and CRGA5 showed $42 \%$ identity ( $\mathrm{E}$ value $7 \mathrm{e}^{-10}$ and $6 \mathrm{e}^{-26}$, respectively) with resistance gene candidate NBS-type protein of Musa acuminata subsp malaccensis. CRGA1 showed 34\% identity (E value 0.033 ) with NBS-LRR resistance-like protein RGC344 of Helianthus annus. Similarly, CRGA2 showed $43 \%$ identity (E value 0.064 ) with a hypothetic resistance protein from Vitis vinifera.

\begin{tabular}{|c|c|c|c|c|}
\hline Curcuma NBS & GenBank protein accession showing the highest similarity & GenBank ID & Amino acid identity $(\%)$ & E value $^{\mathrm{a}}$ \\
\hline \multirow[t]{2}{*}{ CRGAI } & $\begin{array}{l}\text { NBS-LRR resistance-like protein RGC344, } \\
\text { Helianthus annus }\end{array}$ & ABQ57659 & 34 & 0.033 \\
\hline & $\begin{array}{l}\text { NBS-LRR resistance-like protein RGC344, } \\
\text { Helianthus desertcola }\end{array}$ & ABQ57915 & 34 & 0.044 \\
\hline CRGA2 & Hypothetical protein, Vitis vinifera & CAN74100 & 43 & 0.064 \\
\hline \multirow[t]{3}{*}{$C R G A 3$} & $\begin{array}{l}\text { Resistance gene candidate NBS-type protein, } \\
\text { Musa acuminata subsp malaccensis }\end{array}$ & ABY75804 & 42 & $7 e-30$ \\
\hline & Resistance protein, Vitis dividii & ABS50350 & 39 & $4 e-26$ \\
\hline & $\begin{array}{l}\text { NBS-containing resistance-like protein, } \\
\text { Corylus avellana }\end{array}$ & ACN87572 & 39 & $6 e-26$ \\
\hline \multirow[t]{3}{*}{$C R G A 4$} & $\begin{array}{l}\text { Resistance gene analog } \\
\text { (Solanum phureja } \mathrm{x} \text { S. stenotomum) }\end{array}$ & AAL30114 & 65 & $7 e-13$ \\
\hline & $\begin{array}{l}\text { Putative disease resistance protein NBS-LRR, } \\
\text { Solanum dimissum }\end{array}$ & ACE81158 & 61 & $3 e-11$ \\
\hline & NBS-LRR protein, Solanum tuberosum & ABR29793 & 85 & $2 \mathrm{e}-11$ \\
\hline \multirow[t]{2}{*}{ CRGA5 } & $\begin{array}{l}\text { Resistance gene candidate NBS-type protein, } \\
\text { Musa acuminata subsp malaccensis }\end{array}$ & ABY75804 & 42 & $6 e-28$ \\
\hline & $\begin{array}{l}\text { NBS-LRR-type resistance protein } \\
\text { (Cynodon magennisii) }\end{array}$ & ADC54150 & 39 & $5 e-26$ \\
\hline
\end{tabular}

${ }^{a} \mathrm{E}$ value refers to the number of matches expected by chance. The lower the $\mathrm{E}$ value, the greater the similarity is and stronger the match is. 


\section{Multiple sequence alignment with known R-genes}

The amino acid sequences of Curcuma NBS analogs were compared with other known genes, viz. RPS2 and RPM1 of Arabidopsis thaliana, in the NBS region using the CLUSTALX multiple alignment program (Figure 2). The various motifs of NBS, i.e., kinase$1 \mathrm{a}$ and kinase-2, were found conserved in the five selected Curcuma NBS analogs. The five Curcuma NBS were found to have the highly conserved P-loop (GGVGKTT) kinase-1a domain. The hydrophobic domain GLPL was also observed in all five RGA sequences. High sequence similarity of the RGAs with the NBS domains of RPS2 and RPM1 suggests that the RGAs isolated in this study may be grouped into the NBS-LRR class of R-genes. Three of five Curcuma NBS analogs also have a conserved tryptophan (W) residue at the end of the kinase-2 domain, further confirming their similarity to the non-TIR (Toll-interleukin-1 receptor-like domain) subfamily of the NBS-LRR class of R-genes.

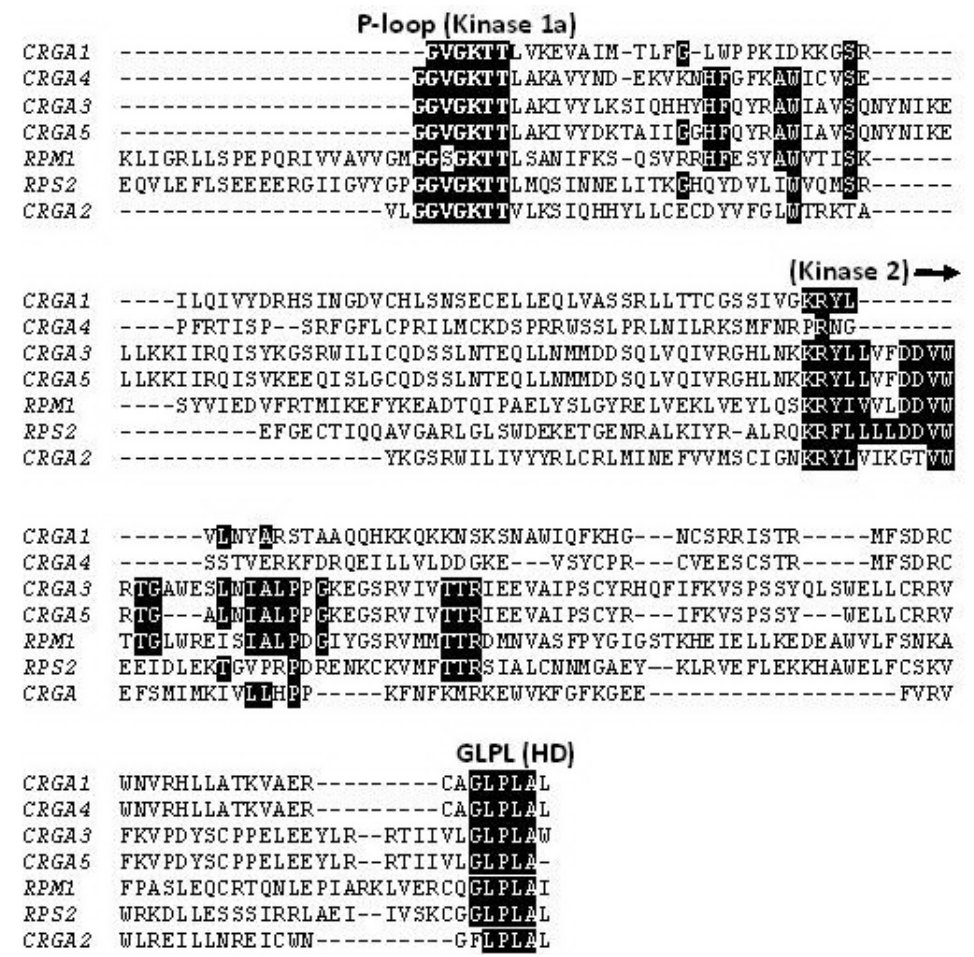

Figure 2. Multiple alignment of deduced amino acid sequences of resistance gene analogs with known NBS-LRR class R-genes RPS2 (GenBank accession No. U12860) and RPM1 (GenBank accession No. NM_111584), using CLUSTALX. Motifs identified are given at the top of the panel. P-loop and GLPL are the priming sites.

\section{Phylogenetic analysis}

Phylogenetic analysis of Curcuma NBS sequences with already characterized R-genes was done by constructing an average distance tree using \% identity in the Jalview Java editor of CLUSTALX. All five Curcuma NBS analogs were grouped with the well-characterized 
non-TIR-NBS-LRR gene RPS2, while the TIR-NBS-LRR genes $N$ and $L 6$ were grouped separately (Figure 3). The RPM1 of Arabidopsis was also placed separate from the major cluster.

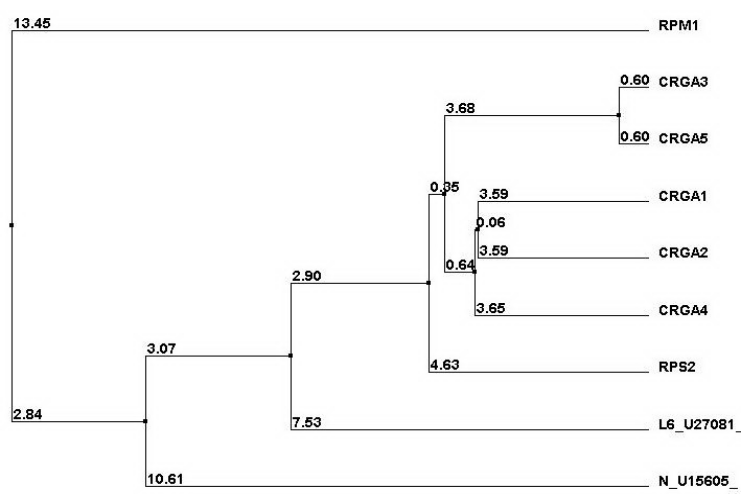

Figure 3. Average distance tree using \% identity showing relationship of Curcuma NBS analogs with NBS-LRR class of R-genes.

Another average distance tree was constructed using the \% identity algorithm for comparing the Curcuma NBS analogs sequenced in this study and as many as 16 well-characterized RGAs isolated from different plant types. Of this, 7 RGAs were from Zingiber officina$l e$, another member of the family Zingiberaceae to which Curcuma belongs. The phylogenetic tree grouped the five Curcuma NBS analogs into two classes as classified by Cannon et al. (2002). The $C R G A 1, C R G A 2$ and $C R G A 4$ were grouped with sequences belonging to non-TIR clade N3 (Figure 4). Two of the Zingiber RGAs Zop26 and Zop27 and R-gene RPS2 were also grouped with them. $C R G A 3$ and $C R G A 5$ were grouped with non-TIR clade N4 along with rest of the five ginger RGAs as classified by Cannon et al. (2002).

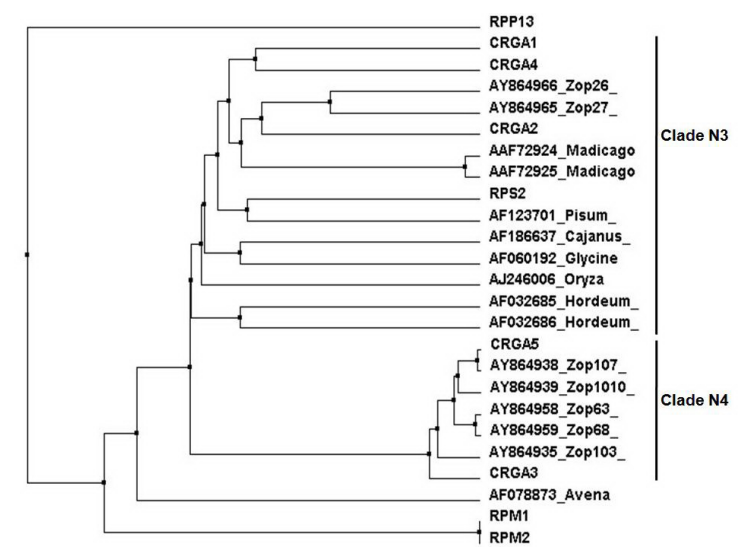

Figure 4. Average distance tree using \% identity of amino acid sequences showing relationship of Curcuma NBS analogs with the characterized NBS domain of R-genes, Arabidopsis RPS2 (U12860), RPP13 (AAF42831), RPM1 (MN_111584), and RPM2 ( ) and RGAs isolated from Zingiber officinale (AY864966, AY864965, AY864935, AY864938, AY864939, AY864958, AY864959), Cajanus cajans (AF186637), Glycine max (AF060192), Oryzae officinalis (AJ246006), Hordeum vulgare (AF032685, AF032686), Madicago sativa (AAF72924, AAF72925), Pisum sativum (AF123701), and Avena sativa (AF078873). 


\section{Comparison of NBS analogs with known R-genes using the BL2SEQ algorithm}

The NBS analogs isolated in the present study were compared with representative NBS-LRR class R-genes, i.e., $N$ gene of tobacco, RPS 2 and RPM1 of A. thaliana and L6 of flux in NBS region using the BL2SEQ algorithm (Tatusova and Madden, 1999). The Rgene analogs showed comparable identity with non-TIR-NBS-LRR genes and TIR-NBS-LRR gene. All five NBS analogs had the lowest $\mathrm{E}$ values with non-TIR-NBS-LRR genes RPS2 and $R P M 1$ as compared to TIR-NBS-LRR gene $N$ and L6 (Table 3). This shows the strong match of the Curcuma NBS analogs with the non-TIR-NBS-LRR gene family. The amino acid identity between the R-genes and the RGAs was also analyzed for comparison using the algorithm. The percentage of identity at the NBS region between RPS2 and N(23\%), RPS 2 and L6 (26\%), $R P M 1$ and $N(27 \%)$, and RPM1 and L6 (22\%) shows that the homology between them was mainly due to different conserved domains of NBS and shows the diversity among the NBSLRR class of R-genes. The extent of identity between the Curcuma NBS analogs ranging between 33 and $83 \%$ reveals the diversity among the NBS analogs isolated in the present study.

\begin{tabular}{|c|c|c|c|c|c|c|c|c|c|}
\hline & CRGAI & $C R G A 2$ & CRGA3 & CRGA4 & CRGA5 & RPS2 & $R P M 1$ & $L 6$ & $N$ \\
\hline$C R G A I$ & $100\left(3 \mathrm{e}^{-88}\right)$ & $35\left(1 \mathrm{e}^{-06}\right)$ & $56(0.013)$ & $100\left(4 \mathrm{e}^{-17}\right)$ & $81(0.024)$ & $49(0.011)$ & $58(0.001)$ & 47 (0.017) & $39(0.17)$ \\
\hline$C R G A 2$ & & $100\left(3 \mathrm{e}^{-78}\right)$ & $33\left(1 \mathrm{e}^{-09}\right)$ & $66(0.004)$ & $80(0.014)$ & $24\left(8 \mathrm{e}^{-04}\right)$ & $21(0.21)$ & $40(0.024)$ & $61(0.013)$ \\
\hline$C R G A 3$ & & & $100\left(5 \mathrm{e}^{-114}\right)$ & $35\left(8 \mathrm{e}^{-10}\right)$ & $87\left(1 \mathrm{e}^{-90}\right)$ & $23\left(1 \mathrm{e}^{-10}\right)$ & $31\left(2 \mathrm{e}^{-22}\right)$ & $25\left(3 \mathrm{e}^{-07}\right)$ & $24\left(1 \mathrm{e}^{-05}\right)$ \\
\hline CRGA4 & & & & $100\left(1 \mathrm{e}^{-86}\right)$ & $33\left(1 \mathrm{e}^{-09}\right)$ & $25\left(2 \mathrm{e}^{-05}\right)$ & $28\left(1 \mathrm{e}^{-06}\right)$ & $30\left(2 \mathrm{e}^{-05}\right)$ & $27\left(6 \mathrm{e}^{-04}\right)$ \\
\hline CRGA5 & & & & & $100\left(2 \mathrm{e}^{-106}\right)$ & $22\left(2 \mathrm{e}^{-09}\right)$ & $32\left(8 \mathrm{e}^{-20}\right)$ & $26\left(1 \mathrm{e}^{-06}\right)$ & $27\left(1 \mathrm{e}^{-04}\right)$ \\
\hline RPS2 & & & & & & $100(0.0)$ & $25\left(1 \mathrm{e}^{-35}\right)$ & $26\left(7 e^{-16}\right)$ & $23\left(3 \mathrm{e}^{-14}\right)$ \\
\hline$R P M I$ & & & & & & & $100(0.0)$ & $22\left(8 \mathrm{e}^{-14}\right)$ & $27\left(8 \mathrm{e}^{-12}\right)$ \\
\hline$L 6$ & & & & & & & & $100(0.0)$ & $35\left(2 \mathrm{e}^{-93}\right)$ \\
\hline$N$ & & & & & & & & & $100(0.0)$ \\
\hline
\end{tabular}

\section{DISCUSSION}

Degenerate primers based on conserved motifs among the NBS-LRR class resistance genes were used in a PCR-based strategy for isolating and characterizing Curcuma NBS analogs in this study. The three degenerate sets of primers were efficient enough to produce target-specific fragments as expected from the distance between the sequence motifs in RPS2 of $A$. thaliana besides some non-specific amplicons. In each primer pair, forward primer was expected to anneal to kinase-1a (P-loop) domain and the reverse primer to the hydrophobic (GLPL) domain. The non-specific fragments were also sequenced and found to be non-homologous to any of the known R-genes or NBS analogs. In earlier studies, co-amplification of non-specific fragments apart from the expected amplicons has been observed in crops such as soybean (Yu et al., 1996), rice (Mago et al., 1999), grapes (Di Gaspero and Cipriani, 2002), and sorghum (Totad et al., 2005). DNA fragments of 500-600 bp were considered to be specific for RGA amplicons as earlier attempts with 300 and $900 \mathrm{bp}$ did not produce any significant homology to known R-genes (Aarts et al., 1998; Lopez et al., 2003; Totad et al., 2005).

The nucleotide sequences obtained in this study were translated to polypeptides and the identity search was then made using the BLASTp algorithm. This was done because of two basic regions. First, it is well known that protein level search and comparison have shown more homology with NBS-LRR region of many RGAs than at the nucleotide level due to 
degeneracy of the genetic code. Second, amino acid sequence has a greater chance to be conserved around the structural motifs, which indicate their functional relevance to resistance genes from which they are made. Thus pair-wise comparison at the amino acid level is more reliable than nucleotide-nucleotide comparison and it has been exploited to establish the identity of RGAs from different species (Totad et al., 2005; Thirumalaiandi et al., 2008).

Multiple sequence alignment of the selected Curcuma analogs and known R-genes showed significant homology to the kinase-1a, kinase-2 and hydrophic GLPL motifs of the NBS domain of the known genes. All five Curcuma NBS analogs were also classified into the non-TIR-NBS-LRR subfamily of the R-genes. The NBS-LRR classes of genes are classified into two subfamilies: The TIR-NBS-LRR subfamily, which is characterized by the presence of a highly conserved aspartic acid (D) or aspartate (N) as the last residue of the kinase-2 domain, and the non-TIR-NBS-LRR subfamily with a highly conserved tryptophan (W) as the last residue of the kinase-2 domain (Pan et al., 2000). Moreover, both TIR and non-TIR-NBSLRR subclasses are present in dicots, but in monocots only the non-TIR subclass is present and the other one is completely absent (Meyers et al., 1999; Cannon et al., 2002). This clearly supports the hypothesis that $C$. longa, being monocotyledonous, has resistance genes of the non-TIR-NBS-LRR class.

The cluster analysis of the NBS analogs identified their group based on similarity. The phylogenetic tree based on neighbor joining using \% identity of the deduced amino acid sequences of Curcuma NBS analogs identified their relatedness with each other as well with the known R-genes RPS2, a well-known non-TIR-NBS-LRR gene (Kanazin et al., 1996) that was characterized with CRGAs isolated in this study, while TIR-NBS-LRR genes $N$ and $L 6$ were placed separately. Another distance tree was made between the Curcuma NBS analogs and RGAs from other studies. The phenetic tree classified the Curcuma CRGAs into two subclasses, $C R G A 1, C R G A 2$ and $C R G A 4$ were grouped with sequences belonging to non-TIR clade N3, and $C R G A 3$ and $C R G A 5$ were grouped with non-TIR clade N4. Earlier, Nair and Thomas (2007) also found similar results while classifying ginger-resistance gene candidates. They demonstrated the existence of two subclasses. Subclass I with clones Zop 26 and Zop 27 in clade N3 and subclass II with 10 other clones in clade N4. We used the same gingiber clones in the present study and grouped the Curcuma NBS analogs into two subclasses as demonstrated in Zingiber officinale. This similarity may be due to the fact that both Curcuma and ginger belong to the same family Zingiberaceae and show greater homology of high evolutionary significance. However, the isolation, sequencing and analysis of more and more Curcuma NBS analogs are required to gain better knowledge about the CRGAs and draw further conclusions.

Research into the nature of R-genes and RGAs has been greatly accelerated in different plant species in recent times. Information on more resistance gene sequences is necessary to detect more structural motifs, which are the basis for the search of resistance gene analogs in crop plants (Totad et al., 2005). The present study demonstrates that degenerate primers based on conserved domains of resistance genes can be used to isolate analogous sequences in Curcuma longa. The five CRGAs identified in this study can be greatly used to clone and characterize R-genes in Curcuma and related plant species. In general, the NBS-LRR class of R-genes consists of hundreds of paralogs in plant species (Meyers et al., 1999). With the help of the identified Curcuma RGAs, different primer sets can be designed for analysis of Curcu$m a$ wild relatives to target novel genomic resources for the genetic improvement of Curcuma. 


\section{ACKNOWLEDGMENTS}

We thank Prof. Dr. M.R. Nayak, President, Siksha O Anusandhan University for his encouragement. We also thank Dr. Pradeep Nayak for help designing the primers.

\section{REFERENCES}

Aarts MG, te Lintel HB, Holub EB, Beynon JL, et al. (1998). Identification of R-gene homologous DNA fragments genetically linked to disease resistance loci in Arabidopsis thaliana. Mol. Plant Microbe Interact. 11: 251-258.

Baker B, Zambryski P, Staskawicz B and Dinesh-Kumar SP (1997). Signaling in plant-microbe interactions. Science 276: 726-733.

Baldi P, Patocchi A, Zini E, Toller C, et al. (2004). Cloning and linkage mapping of resistance gene homologues in apple. Theor. Appl. Genet. 109: 231-239.

Bent AF, Kunkel BN, Dahlbeck D, Brown KL, et al. (1994). RPS2 of Arabidopsis thaliana: a leucine-rich repeat class of plant disease resistance genes. Science 265: 1856-1860.

Cannon SB, Zhu H, Baumgarten AM, Spangler R, et al. (2002). Diversity, distribution, and ancient taxonomic relationships within the TIR and non-TIR NBS-LRR resistance gene subfamilies. J. Mol. Evol. 54: 548-562.

Collins NC, Webb CA, Seah S, Ellis JG, et al. (1998). The isolation and mapping of disease resistance gene analogs in maize. Mol. Plant Microbe Interact. 11: 968-978.

Deng Z, Huang S, Ling P, Chen C, et al. (2000). Cloning and characterization of NBS-LRR class resistance-gene candidate sequences in citrus. Theor. Appl. Genet. 101: 814-822.

Di Gaspero G and Cipriani G (2002). Resistance gene analogs are candidate markers for disease-resistance genes in grape (Vitis spp.). Theor. Appl. Genet. 106: 163-172.

Doyle JJ and Doyle JL (1990). Isolation of Plant DNA from fresh tissue. Focus 12: 13-15.

Duke JA (2003). CRC Handbook of Medicinal Spices. CRC Press, Boca Raton.

Feuillet C, Schachermayr G and Keller B (1997). Molecular cloning of a new receptor-like kinase gene encoded at the Lr10 disease resistance locus of wheat. Plant J. 11: 45-52.

Flor HH (1956). The complementary genic systems in flax and flax rust. Adv. Genet. 8: 29-54.

Gassmann W, Hinsch ME and Staskawicz BJ (1999). The Arabidopsis RPS4 bacterial-resistance gene is a member of the TIR-NBS-LRR family of disease-resistance genes. Plant J. 20: 265-277.

Hammond-Kosack KE and Jones JD (1997). Plant disease resistance genes. Annu. Rev. Plant Physiol. Plant Mol. Biol. 48: 575-607.

He CY, Tian AG, Zhang JS, Zhang ZY, et al. (2003). Isolation and characterization of a full-length resistance gene homolog from soybean. Theor. Appl. Genet. 106: 786-793.

Ilag LL, Yadav RC, Huang N, Ronald PC, et al. (2000). Isolation and characterization of disease resistance gene homologues from rice cultivar IR64. Gene 255: 245-255.

Kanazin V, Marek LF and Shoemaker RC (1996). Resistance gene analogs are conserved and clustered in soybean. Proc. Natl. Acad. Sci. U. S. A. 93: 11746-11750.

Lacock L, Van Niekerk C, Loots S, Du Preez F, et al. (2003). Functional and comparative analysis of expressed sequences from Diuraphis noxia infested wheat obtained utilizing the conserved nucleotide binding site. Afr. J. Biotechnol. 2: 75-81.

Lawrence GJ, Finnegan EJ, Ayliffe MA and Ellis JG (1995). The L6 gene for flax rust resistance is related to the Arabidopsis bacterial resistance gene RPS2 and the tobacco viral resistance gene N. Plant Cell 7: 1195-1206.

Lopez CE, Acosta IF, Jara C, Pedraza F, et al. (2003). Identifying resistance gene analogs associated with resistances to different pathogens in common bean. Phytopathology 93: 88-95.

Mago R, Nair S and Mohan M (1999). Resistance gene analogues from rice: cloning, sequencing and mapping. Theor. Appl. Genet. 99: 50-57.

Meyers BC, Dickerman AW, Michelmore RW, Sivaramakrishnan S, et al. (1999). Plant disease resistance genes encode members of an ancient and diverse protein family within the nucleotide-binding superfamily. Plant J. 20: 317-332.

Nair RA and Thomas G (2007). Evaluation of resistance gene (R-gene) specific primer sets and characterization of resistance gene candidates in ginger (Zingiber officinale Rosc.). Curr. Sci. 93: 61-66.

Ohmori T, Murata M and Motoyoshi F (1998). Characterization of disease resistance gene-like sequences in near-isogenic lines of tomato. Theor. Appl. Genet. 96: 331-338.

Page RD (1996). TreeView: an application to display phylogenetic trees on personal computers. Comput. Appl. Biosci. 
12: $357-358$

Pan Q, Wendel J and Fluhr R (2000). Divergent evolution of plant NBS-LRR resistance gene homologues in dicot and cereal genomes. J. Mol. Evol. 50: 203-213.

Ravindran PN, Nirmalbabu K and Sivaraman K (2007). Turmeric: The Genus Curcuma (Medicinal and Aromatic Plants - Industrial Profiles). CRC Press, Florida.

Rivkin MI, Vallejos CE and McClean PE (1999). Disease-resistance related sequences in common bean. Genome 42: 41-47.

Saitou N and Nei M (1987). The neighbor-joining method: a new method for reconstructing phylogenetic trees. Mol. Biol. Evol. 4: 406-425.

Selvan MT, Thomas KG and Manojkumar K (2002). Ginger (Zingiber officinale Rosc.). In: Indian Spices - Production and Utilization (Singh HP, Sivaraman K and Selvan MT, eds.). Coconut Development Board, Calicut, 110-131.

Shen KA, Meyers BC, Islam-Faridi MN, Chin DB, et al. (1998). Resistance gene candidates identified by PCR with degenerate oligonucleotide primers map to clusters of resistance genes in lettuce. Mol. Plant Microbe Interact. 11: 815-823.

Song WY, Wang GL, Chen LL, Kim HS, et al. (1995). A receptor kinase-like protein encoded by the rice disease resistance gene, Xa21. Science 270: 1804-1806.

Tatusova TA and Madden TL (1999). BLAST 2 Sequences, a new tool for comparing protein and nucleotide sequences. FEMS Microbiol. Lett. 174: 247-250.

Thirumalaiandi R, Selvaraj MG, Rajasekaran R and Subbarayalu M (2008). Cloning and characterization of resistance gene analogs from underexploited plant species. Electr. J. Biotechnol. 11: 1-11.

Thompson JD, Gibson TJ, Plewniak F, Jeanmougin F, et al. (1997). The CLUSTAL_X windows interface: flexible strategies for multiple sequence alignment aided by quality analysis tools. Nucleic Acids Res. 25: 4876-4882.

Totad AS, Fakrudin B and Kuruvinashetti MS (2005). Isolation and characterization of resistance gene analogs (RGAs) from sorghum (Sorghum bicolor L. Moench). Euphytica 143: 179-188.

Traut TW (1994). The functions and consensus motifs of nine types of peptide segments that form different types of nucleotide-binding sites. Eur. J. Biochem. 222: 9-19.

Whitham S, Dinesh-Kumar SP, Choi D, Hehl R, et al. (1994). The product of the tobacco mosaic virus resistance gene N: similarity to Toll and the interleukin-1 receptor. Cell 78: 1101-1115.

Yu YG, Buss GR and Maroof MA (1996). Isolation of a superfamily of candidate disease-resistance genes in soybean based on a conserved nucleotide-binding site. Proc. Natl. Acad. Sci. U. S. A. 93: 11751-11756.

Zhang LP, Khan A, Nino-Liu D and Foolad MR (2002). A molecular linkage map of tomato displaying chromosomal locations of resistance gene analogs based on a Lycopersicon esculentum x Lycopersicon hirsutum cross. Genome 45: $133-146$ 